\title{
Southern California
} Earthquake Center-SCEC1 Final Technical Report Summary Alternative Earthquake Source Characterizations for the Los Angeles Region

\author{
B. Foxall
}

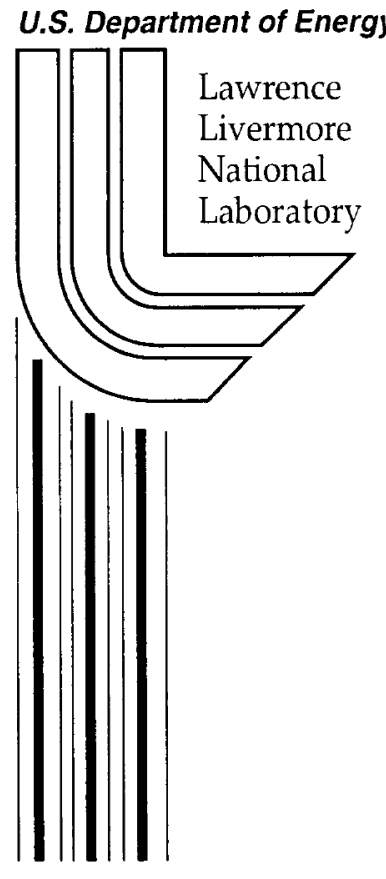

February 26, 2003 


\section{DISCLAIMER}

This document was prepared as an account of work sponsored by an agency of the United States Government. Neither the United States Government nor the University of California nor any of their employees, makes any warranty, express or implied, or assumes any legal liability or responsibility for the accuracy, completeness, or usefulness of any information, apparatus, product, or process disclosed, or represents that its use would not infringe privately owned rights. Reference herein to any specific commercial product, process, or service by trade name, trademark, manufacturer, or otherwise, does not necessarily constitute or imply its endorsement, recommendation, or favoring by the United States Government or the University of California. The views and opinions of authors expressed herein do not necessarily state or reflect those of the United States Government or the University of California, and shall not be used for advertising or product endorsement purposes.

This work was performed under the auspices of the U. S. Department of Energy by the University of California, Lawrence Livermore National Laboratory under Contract No. W-7405-Eng-48.

This report has been reproduced directly from the best available copy.

Available electronically at http://www.doc.gov/bridge

Available for a processing fee to U.S. Department of Energy

And its contractors in paper from

U.S. Department of Energy

Office of Scientific and Technical Information

P.O. Box 62

Oak Ridge, TN 37831-0062

Telephone: (865) 576-8401

Facsimile: (865) 576-5728

E-mail: reports@adonis.osti.gov

Available for the sale to the public from

U.S. Department of Commerce

National Technical Information Service

5285 Port Royal Road

Springfield, VA 22161

Telephone: (800) 553-6847

Facsimile: (703) 605-6900

E-mail: orders@ntis.fedworld.gov

Online ordering: http://www.ntis.gov/ordering.htm

\section{OR}

Lawrence Livermore National Laboratory

Technical Information Department's Digital Library

http://www.llnl.gov/tid/Library.html 


\title{
Southern California Earthquake Center - SCEC1
}

\section{Final Technical Report}

\begin{abstract}
SUMMARY
Alternative Earthquake Source Characterizations for the Los Angeles Region
\end{abstract}

\author{
Bill Foxall \\ Lawrence Livermore National Laboratory
}

The objective my research has been to synthesize current understanding of the tectonics and faults of the Los Angeles Basin and surrounding region to quantify uncertainty in the characterization of earthquake sources used for geologically- and geodetically-based regional earthquake likelihood modeis. This work has focused on capturing epistemic uncertainty; i.e. uncertainty stemming from ignorance of the true characteristics of the active faults in the region and of the tectonic forces that drive them. In the present context, epistemic uncertainty has two components: First, the uncertainty in source geometrical and occurrence rate parameters deduced from the limited geological, geophysical and geodetic observations available; and second, uncertainties that result from fundamentally different interpretations of regional tectonic deformation and faulting.

Characterization of the large number of active and potentially active faults that need to be included in estimating earthquake occurrence likelihoods for the Los Angeles region requires synthesis and evaluation of large amounts of data and numerous interpretations. This was accomplished primarily through a series of carefully facilitated workshops, smaller meetings involving key researchers, and email groups. The workshops and meetings were made possible by the unique logistical and financial resources available through SCEC, and proved to be extremely effective forums for the exchange and critical debate of data and interpretations that are essential in constructing fully representative source models.

The main products from this work are a complete source model that characterizes all know or potentially active faults in the greater Los Angeles region, which includes the continental borderland as far south as San Diego, the Ventura Basin, and the Santa Barbara Channel. The model constitutes a series of maps and representative cross-sections that define alternative fault geometries, a table containing fault geometrical and slip-rate parameters, including full uncertainty distributions, and a set of logic trees that define alternative source characterizations, particularly for sets of fault systems having inter-dependent geometries and kinematics resulting from potential intersection and interaction in the sub-surface. All of these products exist in a form suitable for input to earthquake likelihood and seismic hazard analyses. In addition, moment-balanced Poissonian earthquake rates for the alternative multi-segment characterizations of cach fault system have been estimated.

Finally, this work has served an important integrative function in that the exchange and debate of data, results and ideas that it has engendered has helped to focus SCEC research over the past six years on to key issues in tectonic deformation and faulting. 


\title{
SCEC1 FINAL REPORT
}

\author{
Bill Foxall \\ Lawrence Livermore National Laboratory
}

\section{Alternative Earthquake Source Characterizations for the Los Angeles Region}

\section{Introduction}

The objective my research has been to synthesize current understanding of the tectonics and faults of the Los Angeles Basin and surrounding region (including the inner continental borderland) to quantify uncertainty in the characterization of earthquake sources used for geologically- and geodetically-based regional earthquake likelihood models. This work has focused on capturing epistemic uncertainty; i.e. uncertainty stemming from ignorance of the true characteristics - in some cases, the existence - of the active faults in the region and of the tectonic forces that drive them. In the present context, epistemic uncertainty has two components: First, the uncertainty in source geometrical and occurrence rate parameters deduced from the limited geological, geophysical and geodetic observations available; and second, uncertainties that result from fundamentally different interpretations of regional tectonic deformation and faulting. This report deals with the alternative source models that result from uncertainties of the second type. The full source characterization, including both parametric and model uncertainty for all potential sources in the region will be posted on the SCEC web site.

\section{Approach}

Characterization of the large number of active and potentially active faults that need to be included in estimating earthquake occurrence likelihoods for the Los Angeles region requires synthesis and evaluation of large amounts of data and numerous interpretations produced by SCEC and other scientists. This was accomplished primarily through a series of carefully facilitated workshops, smaller meetings involving key researchers on given topics, and email groups. The workshops and meetings were made possible by the unique logistical and financial resources available through SCEC, and proved to be extremely effective forums for the exchange and critical debate of data and interpretations that are essential in constructing fully representative source models (e.g. Senior Seismic Hazard Analysis Committee, 1997). Furthermore, SCEC's programmatic approach enabled the source characterization to evolve over time by focusing research efforts and day-to-day discussion on some of the key geological and tectonic issues that came to light during the process. Current geological results for the Los Angeles Basin are summarized in the SCEC Group C report, ht!p//WwW scecorg/rescarch/special/SCECOOlaclivetiultsLA.pdt.

\section{Alternative Source Characterizations}

Alternative characterizations for a given fault system are required when viable interpretations of the data support distinctly different geometries, faulting styles, or slip rates. In the Los Angles region the main (but not only) tectonic issue that leads to alternative characterizations remains the postulated existence of active regional-scale, blind, shallow-dipping thrusts and detachments that can accommodate part of the N-NE directed shortening observed geodetically across the region. Postulated blind faults underlie mapped active, steeply dipping surface faults, and, in certain cases, the shallow- and steeplydipping fault systems must intersect and interact kinematically within the seismogenic crust. Therefore, the blind faults are not only potentially significant earthquake sources themselves, but also imply geometric and kinematic dependencies that have a major influence on the characterization of some surface faults. The blind faults are seldom imaged directly, other than perhaps in the top few kilometers of the crust, so their geometries and kinematics are most often constrained only by structural modeling of surface folding. Generally, such modeling is highly non-unique, which leads to wide ranges of plausible alternative configurations for the blind faults, and hence for the fault systems they interact with.

This report describes the development of alternative characterizations for three cases that make significant contributions to uncertainty in earthquake likelihood estimates. The two parts of the source model that cover these cases are shown in Fig. 1. The source model represents known and postulated active faults as rectangular fault sections. These are assembled into fault segments, each of which is the smallest fault unit that is considered to be capable of rupturing independently, generating earthquakes of a 
characteristic sizc. Contiguous segments of a given fault can also combine to fail in multi-segment ruptures ("cascades") (e.g. Jackson et al., 1995).

The alternative characterizations for inter-dependent fault systems are developed using logic trees like the one shown in Fig. 3. The branch tips on the right of each tree (or sub-tree) correspond to mutually exclusive alternative sets of earthquake sources. For clarity, only the longest multi-segment source for each fault system is shown in the logic trees, but single- or shorter multi-segment ruptures are of course also permitted. As normally used for earthquake probability or hazard analysis, each branch at each decision point is assigned a weight expressing the relative likelihood that it represents the true description of the system. The aim of the work described here, however, is to develop the structure of each tree, without weighting the branches. Summaries of the arguments upon which the trees are based and references to the original data sources are given to allow users to determine their own branch weights. Parameter distributions for each alternative source will be posted the SCEC-RELM web page.

\section{Malibu-Northern Los Angeles Basin Left-oblique System and Santa Monica Mountains Thrust}

The left-lateral/left-reverse faults bounding the Los Angeles Basin and Santa Monica Bay on the north (Fig. 1a) are characterized under the assumption that they form a system that can break in multisegment ruptures and that is continuous with the Santa Cruz Island-Santa Rosa Island system to the west. Alternative characterizations of this system also include the possible existence of an active Santa Monica Mountains thrust, as shown in cross-sections BB' and CC' (Fig. 2). The logic tree shown in Fig. 3 is developed from left to right (Columns 1-9), following the reasoning summarized below:

1. Left-lateral slip on the Santa Cruz. Island fault could be transferred eastward to the onshore Santa Monica fault via either the Malibu Coast fault or the Dume and offshore Santa Monica faults (Dolan et al., 2000), or be partitioned between these systems (Cols. 1-2). The eastern end of the Santa Cruz Island fault appears to be continuous with the Malibu Coast fault, but it is also possible that slip could be transferred to the western end of the Dume fault across a zone of complex faulting (C. Sorlien, personal communication). The Malibu Coast fault appears to have a very low slip rate $(<0.5 \mathrm{~mm} / \mathrm{yr})$, and may be inactive. There is increasing evidence, however, that the Dume fault $\mathrm{W}$ of $\mathrm{Pt}$. Dume may accommodate significant left-lateral slip (Dolan ct al., 2000; Sorlien et al., 2001). Sorlien and Kammerling (C. Sorlien. written communication) have seismic evidence that the Dume fault continues E of Pt. Dume, striking ENE, and propose that left-lateral slip on the offshore Santa Monica fault of Dolan et al. (2000) is transferred to the Dume fault across a $\approx 2 \mathrm{~km}$ left step (Fig. 1). They propose, therefore, that the WNWstriking fault $\mathrm{W}$ of $\mathrm{Pt}$. Dume is a restraining segment that experiences left-reverse slip. There is evidence that slip on the onshore Santa Monica fault is left-reverse (Dolan et al., 2000), but the left-lateral rate is not constrained.

2. Based on Dolan et al. (2000) the Santa Monica fault is estimated to dip $65^{\circ} \mathrm{N}$ (Col. 3) and to root into the $20^{\circ} \mathrm{N}$-dipping blind Santa Monica Mountains thrust at a depth of about $14 \mathrm{~km}$ (Fig. 2b), as proposed by Davis and Namson (1994). Alternatively, T'sutsumi et al. (2001) propose that the Santa Monica fault dips $45^{\circ}$ at depth and is the upward continuation of an active Santa Monica Mountains thrust that dips $>45^{\circ} \mathrm{N}$ (fig. 2b). In this scenario the eastern part of the Malibu Coast fault is truncated at shallow depth by the Santa Monica fault, and is therefore not considered a significant earthquake source.

3. Gravity and air-photo lincations suggest that the Raymond fault may be continuous with the Hollywood fault, but this has not been confirmed by mapping (Weaver and Dolan, 2000) (Col. 5).

4. Recent analyses (e.g. Meigs et al., 1999) indicate that the Santa Monica Mountains thrust is slipping at a rate $\sim 0.1 \mathrm{~mm} / \mathrm{yr}$, much slower than the rate proposed by Davis and Namson (1994), and even that the thrust may not be active (Col. 7). The dip-slip rate in the model of Tsutsumi et al. (2001) is < $<3 \mathrm{~mm} / \mathrm{yr}$. Based on seismicity, Seeber and Sorlien (unpublished) suggest that the thrust may extend under and south of the Dume fault up to a depth of about $8 \mathrm{~km}$ (Col. 8) (sce also Dolan et al., 2000).

Compton-Los Alamitos Thrust, Palls Verdes and Newport-Inglewood Faults

Shaw and Suppe (1996) (referred to as SS96) modeled the Compton-Los Alamitos (CL) thrust as a ramp dipping $20^{\circ}-25^{\circ} \mathrm{NE}$ with an average dip-slip rate of $1.4 \pm 0.4 \mathrm{~mm} / \mathrm{yr}$ since $\approx 2.5 \mathrm{Ma}$. SS96 proposed 
two alternative models (their Fig. 6). In the first the ramp flattens to horizontal decollements at its lower and upper edges, generating the CL and Torrence-Wilmington-Belmont (TWB) fault-bend fold trends, respectively. In the second, the CL trend is generated above a wedge-fault geometry, in which the CL ramp is a backthrust above a lower horizontal decollement and SW-dipping ramp. Ongoing analysis of seismic reflection lines further SW suggests that the TWB trend is a fault-propagation fold above the blind tip of a NE-dipping blind fault, the Wilmington thrust, imaged at about $4 \mathrm{~km}$ depth, which may splay off the CL system (J. Shaw, written communication).

J. Shaw (written communication) also interprets offset reflections under San Pedro Bay as a blind fault dipping about $45^{\circ} \mathrm{SW}$ from a depth of about $4 \mathrm{~km}$, which he suggests may be the deeper plane of the near-vertical surface Palos Verdes fault (PV). Oblique slip on this plane would be partitioned into rightlateral and reverse components in the near surface. Ward and Valensise (1994) (referred to as WV) had previously proposed an oblique-slip plane dipping $65^{\circ} \mathrm{SW}$ under the Palos Verdes peninsular between 6 and $12 \mathrm{~km}$ depth, the base of the seismicity. WV attribute this oblique slip PV plane to the restraining geometry of the onshore segment of the fault (Fig. 1). Shaw's interpretation can be viewed as an alternative geometry for an oblique slip deeper PV plane, although his seismic line passes several $\mathrm{km} \mathrm{SE} \mathrm{of}$ the restraining bend. Alternatively, either plane could be interpreted as a fault separate from a PV that dips near vertically to the base of the seismogenic zone

Fig. 1 shows the $\mathrm{CL}$ ramp of the original SS96 ramp-flat model. The non-uniqueness inherent in the SS96 modeling and interaction of an active CL system with both the active Newport-Inglewood and Palos Verdes faults result in the rather complicated set of alternative characterizations shown in Fig. 4. The cross-sections depict the Wilmington thrust with a nominal dip of $45^{\circ}$ and the Shaw and WV SW-dipping oblique planes as mutually exclusive alternatives. The logic tree shown in Fig. 5 is developed as follows:

1. Recent work by K. Meuller and T. Rockwell (Mueller, 1997; K. Mueller, written communication) including trenching, cone penetrometer profiles and structure contours on dated aquifers strongly suggests that the either the slip rate on the CL system since $\approx 330 \mathrm{Ka}$ is much slower (about $0.3 \mathrm{~mm} / \mathrm{yr}$ ) than the average Pliocene-Quaternary rate derived in SS96, or that the system is now inactive (Col. 1). None of the work reported to date can discriminate between the (modified) ramp-flat and wedge models (Col. 2).

2. One possibility is that the CL terminates as the Wilmington thrust (Col. 3). However, the seismic across the TWB shows only gently folding at the base of the Quaternary, strongly suggesting that Quaternary slip on the CL bypassed the Wilmington thrust, which is probably now inactive (J. Shaw, written communication). Note that the original SS96 interpretation of the CL flattening under the TWB is not supported by the Shaw's more recent interpretation of the folding. The CL ramp can either stop short and refold the upper part of the PV (Fig. 4a), or it can extend into San Pedro Bay (Figs. 4b-d) (Col. 4), perhaps as the source of the San Pedro Bay escarpment. (Characterization of the Cl,-PV interaction is deferred until Cols. 7-9, discussed in (5) below.)

3. SS96 modeling does not constrain the depth of the CL thrust or Central Basin decollement (Col. 5). The minimum depth of the lower fault bend (or the wedge tip) is constrained to $8.5 \mathrm{~km}$ by interpretation of well and seismic data, but the maximum depth could be the base of the seismogenic crust, estimated as $17 \mathrm{~km}$ in this location (Fig. 4).

4. Any scenario that involves an active CL ramp-flat geometry in which the Central Basin decollement is significantly shallower than the base of the seismogenic zone implies that the Newport-Inglewood fault (NI) is offset by the CL, so that the NI is split into segments in the hanging and foot walls of the thrust. Alternative CL, NI and Wilmington thrust source combination scenarios are shown in Col. 6 . The hypocentral location of the 1933 Long Beach earthquake suggests that the hanging wall segment of the NI extends to a depth of at least $12 \mathrm{~km}$. The resulting width of the footwall segment would then be $\leq 5$ $\mathrm{km}$ so that this segment would not be considered a significant earthquake source. However, the possibility of an earthquake nucleating at the base of the seismogenic crust on the foot wall segment and propagating across the offset - presumably involving rupture of that section of the $\mathrm{CL}$ - on to the hanging wall segment is also considered. The feasibility of this scenario depends on the offset distance. Assuming that slip on the NI and CI system initiated at approximately the same time (3-2.5 Ma: SS96). 
the offset is equal to the total slip on the CL, estimated as $4 \mathrm{~km}$ by SS96. This seems like a substantial rupture barrier. This offset could exist even if the $\mathrm{CL}$ became inactive $\approx 330 \mathrm{ka}$ or later. The opposite alternative (no offset) is that the NI extended downwards to form a single, near vertical plane to the base of the seismogenic zone once the CL became inactive. Only the latter alternative is implemented in the logic tree branch (Col. 1) for an inactive CL.

5. If the CL extends into San Pedro Bay (Col. 4), then it must interact with the PV. The several alternative possibilities for the interaction, shown as sub-trees $(A)-(E)$, depend on the choice of the ramp-flat or wedge model (Col. 2) and depth to the ramp or wedge (Col. 5). The resulting PV source combination scenarios in Col. 9 are combined with the NI-CL-W scenarios in Col. 5.

(A) corresponds to Fig. 4e where the depth to the upper decollement of a wedge is $12 \mathrm{~km}$ - coinciding with the estimated base of the scismogenic zone - or greater, and to all cases in which the CL stops short of the PV (e.g. Fig. 4a). In these cases the CL does not interact with the PV within the seismogenic crust. The sub-vertical PV in the shallow subsurface can be either continuous with a SWdipping plane at depth or can extend vertically through the seismogenic crust (Col. 7). In the latter case the SW-dipping plane is considered to be a separate blind fault. The Shaw or WV SW-dipping geometry is selected in Col. 8 . If the Shaw plane is treated as the downward extension of the PV in Col. 7, then it slip on it is oblique. Treated as a separate fault, it can be either reverse or oblique. Slip on the WV plane is oblique in both cases, in accord with their modeling result.

(B) corresponds to Fig. $4 \mathrm{~b}$ in which the $\mathrm{CL}$ ramp cuts the PVF at a depth about $4 \mathrm{~km}$. This is the minimum depth for the CL/PV intersection, since the PV is imaged seismically as deep as this ( $\mathrm{J}$. Shaw, personal communication). The PV is offset by the CL. ramp. Since the location of the SWdipping plane defined by either Shaw or WV is fixed by observations or modeling, neither can be the continuation of the surface PV, and either is considered only as a separate source in Col. 8. Lacking any other constraint, the PV is considered to be vertical in both the hanging and footwalls of the CL. The range of offset alternatives considered for the NI also applies to the PV, although the offset models for the two faults are not necessarily correlated. It is unlikely that the narrow hanging wall segment of the PV in this scenario is a viable independent source. Therefore, the relatively high slip rate at the surface $(\approx 3 \mathrm{~mm} / \mathrm{yr})$ would require events that nucleate on the wider foot wall segment and propagate on to the hanging wall segment. Here again, the feasibility of this depends on the width of the PV offset.

(C) covers the case where either the CL ramp (Fig. 4c) or wedge upper decollement (Fig. 4f) cut the PV near the upper edge of the WV oblique plane. This scenario is similar to (B), except that Shaw's $\mathrm{SW}$-dipping plane is confined to the $\mathrm{Cl}$. hanging wall, and is not considered a viable source.

(D) covers the case of a ramp-flat model with the Central Basin decollement near the base of the seismogenic crust (Fig. 4d). This scenario is analogous to (A), except that the PV/SW-dipping plane root into the CL ramp above the base of the seismogenic crust.

(E) applies to wedge model cases intermediate between (A) and (C), where the upper decollement cuts the PV between 6 and $12 \mathrm{~km}$ depth. The SW dipping planes are treated the same as in $(A)$, except that they root into the upper decollement and the WV plane is considered too narrow to be a viable independent source. The offset vertical PV is treated the same as in (C). The viability of the hanging wall PV segment as an independent source increases as the decollement becomes deeper.

\section{Oceanside and San Joaquin Thrusts, and Newport-Inglewood and Rose Canyon Faults}

Seismic reflection profiles clearly image an ENE-dipping Miocene low-angle normal detachment underlying the continental shelf between Dana Pt. and Oceanside (Crouch and Suppe, 1993; Bohannon and Geist, 1998). Rivero et al. (2000) (referred to as R00) mapped the detachment from Laguna Beach to the US-Mexican border (Fig. 1b), and proposed that the entire structure has been reactivated since the Late Pliocenc as the Oceanside blind thrust (OT), capable of generating large earthquakes having return periods $\sim 10^{3}$ years. This proposal was based on interpretation of growth strata in the east-vergent San Mateo fold 
and thrust belt (Fischer and Mills, 1991; Crouch and Suppe, 1993) in the hanging wall of the detachment, associated young seafloor scarps along the continental slope, and uplifted marine terraces along the coast. R00 and Mueller et al. (1998) further proposed that the fold crest beneath the shelf slope break is the offshore extension of the San Joaquin Hills (SJH), which they propose are being actively uplifted above a bend in a SW-dipping blind backthrust off the OT, interpreted on offshore seismic profiles to the SE. R00 estimate that the dip of the thrust as about $15^{\circ}$ in the north, increasing to about $25^{\circ}$ offshore San Diego. The geometry shown in Fig. $1 \mathrm{~b}$ is based on the R00 mapping, but divides the thrust into north and south segments. This is based on the distinct bend in the trend of the breakout zone at about $33^{\circ} \mathrm{N}$ shown in $\mathrm{R} 00$, the change in dip across this bend, and the greater intensity and extent of contractional deformation above the northern segment (C. Rivero and J. Shaw, personal communication).

The fold crest along the shelf break interpreted by R00 is coincident with the offshore NI zone interpreted from the seismic data by, among others, Fischer and Mills (1991) and Crouch and Suppe (1993). Several authors have identified this zone as a continuous, active right-lateral transpressive system that connects the onshore NI and Rose Canyon faults. Although in some locations the high-angle faults appear to disrupt the Oceanside detachment, the nature of the interaction is generally unclear. Fischer and Mills suggest that the active, inner compressional complex of the San Mateo system along the mid slope is part of the positive flower structure that they interpret in the vicinity of the shelf break along the length of the NI zone. The OT of R00 appears to correspond to the main thrust of the outer San Mateo complex (in the vicinity of the slope base), which Fischer and Mills suggest is truncated at a shallow depth by the westernmost fault of the inner complex. Alternatively, Crouch and Suppe suggest that east-dipping thrusts of the San Mateo system root into the detachment, which they propose has been reactivated locally under NE-SW regional contraction. They propose that the contractional deformation belt uplifts the NI zone, but that contraction is decoupled from dextral shear. Fischer and Mills divide the offshore NI into Dana Point and Oceanside segments (Fig. Ib), both having a preferred right-lateral slip rate of $1 \mathrm{~mm} / \mathrm{yr}$.

None of the above interpretations establishes unequivocally whether either the right-lateral system or the thrust is a continuous source capable of generating large earthquakes, or how the two systems might coexist. R00 did not address high-angle faulting along the shelf break as an alternative (or addition) to their seismic interpretation, but did discuss alternative models of interaction between the OT and an assumed active offshore NI. This interaction must take place at depths of approximately $5 \mathrm{~km}$ or less, and further south the OT must also interact with the SE segment of the Coronado Bank fault. The cross-sections in Fig. 6 show alternative modes of interaction, based on the four alternative models proposed by R00. The logic tree is shown in Fig. 7 and discussed below.

1. Direct evidence for reverse separation on the OT is not observed, and lack of control on sediment ages renders evidence for activity based on disruption of the seafloor less than definitive (R00) (Col. 1). R00 used indirect methods to estimate slip rate bounds. A minimum slip rate of $0.3-0.4 \mathrm{~mm} / \mathrm{yr}$ is estimated from the uplift rate of the SJH, and R00 show that this estimate is consistent with marine terrace uplift rates to the south. However, the backthrust (wedge) model for the SJH is open to question [see (6) below], and regional coastal uplift could be attributed other causes (e.g. Kier et al., 2002); if slip on the thrust were responsible for coastal uplift, then the uplift rate would be expected to decrease from north to south as the thrust diverges from the coast and its dip increases. Instead, coastal uplift is essentially constant. Also, tilting that might be expected from slip on the thrust is not observed, and the onset of coastal uplift may post-date the Pliocene initiation of thrusting estimated by R00 ( $T$. Rockwell, personal communication). R00 based a maximum rate of $2.2 \mathrm{~mm} / \mathrm{yr}$ on a geodetic estimate of convergence between the coast and Santa Catalina Island by Kier and Mueller (1999), but recent analyses indicate that convergence is below the noise level $(\approx 1 \mathrm{~mm} / \mathrm{yr}$ ) (Y. Bock, personal communication).

2. Fischer and Mills (1991) strongly assert that the NI is continuous with the Rose Canyon fault and is Quaternary active in the offshore (Col. 2). However, they state that only the $12 \mathrm{~km}$-long segment offshore San Onofre displays convincing evidence for late Holocene displacement, while apparent Holocene slip decreases from Newport Bay to zcro off San Mateo point. In general, Holocene activity is inferred by thinning or absence of sediments interpreted on high-resolution seismic, but these do not appear to have been reliably dated. Therefore, while fault splays within the zone cut the sea floor locally, evidence for Holocene through-going slip is not definitive. 
3. If both the OT and the offshore NI are active, then one alternative (Col. 3) is that they represent local slip partitioning (Lettis and Hanson, 1991) and merge at depth into a single oblique-slip plane (Figs. $6 \mathrm{c}, \mathrm{d})$. The detachment is not imaged at depths greater than about $5 \mathrm{~km}$, so that its dip east of the NI is not constrained. In their oblique slip scenario, R00 assumed that the dip of the oblique-slip plane is the same as the shallow OT. However, in an empirical study of 173 earthquakes Wells and Coppersmith (1991) found no events having rake less than $50^{\circ}$ that occurred on faults dipping less than $45^{\circ}$. Therefore, the oblique-slip plane is shown schematically with a dip of $45^{\circ}$ in Fig. 6. North of Dana Pt. slip on the oblique plane can propagate on to both the shallow thrust and the NI (Fig. 6c). South of Dana P1. the situation is more complex [Fig. 6d; see (5) below)] and the oblique slip model appears less plausible.

4. Other models for the coexistence of the O'T and offshore NI involve regional partitioning of dextral and reverse slip (Lettis and Hanson, 1991). In the first of these models the offshore NI truncates the OT (Fig. 6a), such that only the shallow OT imaged in the seismic is active (Col. 4). In this case the OT is not considered a significant earthquake source. The alternative is that the OT offsets the NI (Fig. 6b). North of Dana Pt. the tip of the wedge of R00 is east of the NI, and the offset model is generally similar to that for the PV-CL (i.e. narrow hanging wall strike-slip segment) (Fig. 6b). However, south of Dana Pt. the NI and fault-bend fold - as they are presently interpreted - are coincident, so that the NI is offset by both the OT and the backthrust. This results in the rather complex situation shown in Fig. 6d, in which it seems improbable that a rupture of the foot wall segment of the NI would propagate to the surface.

5. If the OT is inactive, then active strike slip faults are assumed to extend to the base of the seismogenic crust. As for the NI-CL interaction discussed above, the strike-slip faults conceivably could still be offset as a result of previous slip on the thrust, but this possibility is not considered in the logic tree.

6. The backthrust is an integral part of the R00 model, and has two consequences. First, it structurally links the OT to the SJH (Col. 5), requiring that the northern segment of the OT extend to the northwestern end of the San Joaquin fold (OT-long). Otherwise the OT could terminate south of Dana $\mathrm{Pt}$ (OT-short). The NI Dana Pt. segment is divided into sub-segments north and south of Dana Pt. to accommodate these two alternatives in both the oblique and offset models; OT-long interacts with both the north and south sub-segments, OT-short only with the south sub-segment. Secondly, the SWdipping blind fault (SJ) in the backthrust interpretation is confined to the hanging wall (e.g. Figs, 6b,d) and is not, in itself, considered a significant earthquake source. Alternatively, the preferred model of Grant et al. (1999) locally partitions slip across the NI zone, reverse slip being accommodated on the SJ. The SJ dip is not constrained, but this model permits a steeply dipping fault that extends to seismogenic depth (Col. 6), either as an independent source or as a splay off the NI (e.g. Fig. 6a). One observation that argues against the backthrust model is that the SJH fold and the offshore fold as mapped by Mueller et al. (1998, Fig. 1) plunge to the south and NNW, respectively, and do not trend towards each other as might be expected if the two structures were directly linked.

7. Given the distance from the upper edge of the southern OT segment to the Rose Canyon fault and an estimated dip of $\approx 25^{\circ}$, the OT and Rose Canyon fault intersect at a depth of about $14-15 \mathrm{~km}$. Since this is close to the base of the seismogenic zone, alternative interaction models are not needed. However, the SE segment of the potentially active Coronado Bank fault intersects the OT at a depth of about $6 \mathrm{~km}$. Since this is similar to the OT-NI intersection, arguments analogous to (3)- (5) above are used to construct the sub-trees in Fig 7b, Cols. 7-9, under the assumptions that the slip styles on the NI and Coronado Bank faults are correlated (e.g. oblique slip on one implies oblique slip on the other), and that one active OT segment implies the other segment is also active.

\section{Conclusions}

Current competing hypotheses on tectonic deformation and faulting with in the Los Angeles region result in complex sets of alternative earthquake source characterizations that make a significant contribution to uncertainty in earthquake likelihood and seismic hazard estimates. In this report logic trees are developed that express the alternative source characterizations for the fault system that are judged to contribute the most to the uncertainty. Alternative characterizations for several other systems are also 


\section{Acknowledgement}

This work was performed under the auspices of the U.S. Department of Energy by the University of California, Lawrence Livermore National Laboratory under Contract No. W-7405-Eng-48. 
possible. These include possible interaction between the Whittier and the blind Santa Fe and Coyote faults, the relationship of the regional-scale detachment proposed by Fuis et al (2001) to these faults and the Sierra Madre system , and potential cross-cutting relationship involving the blind Elysian Park fault (Oskin et al., 2000), the Verdugo fault and the Santa Susana fault.

\section{References}

Bohannon, R.G., and E. Geist, Upper crustal structure and Neogene tectonic development of the California continental borderland, Geol. Soc. Am. Bull., 110, 779-800, 1998.

Crouch, J.K., and J. Suppe, Late Cenozoic evolution of the Los Angeles basin and inner California borderland: A model for core complex-like crustal extension, Geol. Soc. Am. Bull, 105, 1415-1434, 1993.

Davis, T.L., and J.S. Namson, A balanced cross-section of the 1994 Northridge earthquake, southern California, Nature, 372, 167-169, 1994.

Dolan, J.F., K. Sieh, and T.K. Rockwell, Late Quaternary activity and seismic potential of the Santa Monica fault system, Los Angeles, California, Geol. Soc. Am. Bull., 112, 1559-1581, 2000.

Fischer, P.J., and G.I. Mills, The offshore Newport-Inglewood-Rose Canyon fault zone, California: Structure, segmentation and tectonics, in Environmental Perils, San Diego Region, P.L. Abbot and W.J. Elliot, eds., 17-36, San Diego Assoc. Geol., 1991.

Fuis, G. S., T. Ryberg, N.J. Godfrey, D.A. Okaya, and J.M. Murphy, Crustal structure and tectonics from the Los Angeles Basin to the Mojave Desert, Southern California, Geology, 29, 15-18, 2001.

Grant, L.B., K.J. Mueller, E.M. Gath, H. Cheng, R.L. Edwards, R. Munro, and G.L. Kennedy, Late Quaternary uplift and earthquake potential of the San Joaquin Hills, southem Los Angeles basin, California, Geology, 27, 1031-1034, 1999.

Jackson, D.D., et al., Seismic hazards in Southern California; probable earthquakes, 1994 to 2024, Bull. Seismol. Soc. Am., 85, 379-439, 1995.

Kier, G., and K. Mueller, Evidence for active shortening in the offshore Borderlands and its implications for blind thrust hazards in the coastal Orange and San Diego counties, Proc. 1999 SCEC Annual Meeting, 71, Southern California Earthquake Center, 1999.

Kicr, G., K. Mueller, and T.K. Rockwell, Origin of regional uplift across southern California and northern Baja California, submitted to Tectonics, 2002.

Lettis, W.R., and K.L. Hanson, Crustal strain partitioning implications for seismic hazard assessment in western California, Geology, 19, 559-562, 1991.

Magistrale, H., and H-w Zhou, Lithologic control of the depth of earthquakes in southern California, Science, 273, 639642,1996

Meigs, A., N. Brozovic, and M.L. Johnson, Steady, balanced rates of uplift and erosion of the Santa Monica Mountains, California, Basin Research, 11, 59-73, 1999

Mueller, K.J., Recency of folding along the Compton-Los Alamitos trend: Implications for seismic risk in the Los Angeles basin, EOS Trans. AGU, 78(46) Suppl., 702, 1997.

Mueller, K., J. Shaw, and C. Rivera, Determining the geometry of the San Joaquin Hills blind thrust: Implications for earthquake source characterization, Progress report submitted to SCEC, 4 p., 1998.

Oskin, M., K. Sieh, T. Rockwell, G. Miller, P. Guptill, M. Curtis, S. McArdle, and P. Elliot, Active parasitic folds on the Elysian Park anticline; implications for seismic hazard in central Los Angeles, California, Geol. Soc. Am. Bull., 112, 693-707, 2000.

Rivero, C., J.H. Shaw, and K. Mueller, Oceanside and Thirtymile Bank blind thrusts: Implications for earthquake hazards in coastal southern California, Geology, 28, 891-894, 2000.

Senior Seismic Hazards Analysis Committee, Recommendations for probabilistic seismic hazard analysis: Guidance on uncertainty and the use of experts, NUREG/CR-6372, US Nuclear Regulatory Commission, Washington, DC, 256 p., 1997.

Shaw, J.H. and J. Suppe, Earthquake hazards of active blind-thrust faults under the central L os Angeles basin, California, Jo. Geophys. Res., 101, 8623-8642, 1996.

Sorlien, C.C., M.J. Kamerling, and L. Seeber, The Dume fault, northern Santa Monica Bay, California, EOS Trans. AGU, 82(47), Abstract S11A-0532, 2001.

Tsutsumi, H., R.S. Yeats, and G.J. Huftile, Late Cenozoic tectonics of the northern Los Angeles fault system, California, Geol. Soc. Am. Bull., 113, 454-468, 2001

Ward, S.N., and G. Valensise, The Palos Verdes terraces, California: Bathtub rings from a buried reverse fault, Jo. Geophys. Res., 99, 4485-4494, 1994.

Weaver, K.D., and J.F. Dolan, Paleoseismology and geomorphology of the Raymond fault, Los Angeles county California, Buil. Seismol. Soc. Am., 90, 1409-1429, 2000.

Wells, D.L., and K.J. Coppersmith, Analysis of fault dip and sense of slip for historical earthquakes, Seismol. Res Lets., 62, 38, 1991 

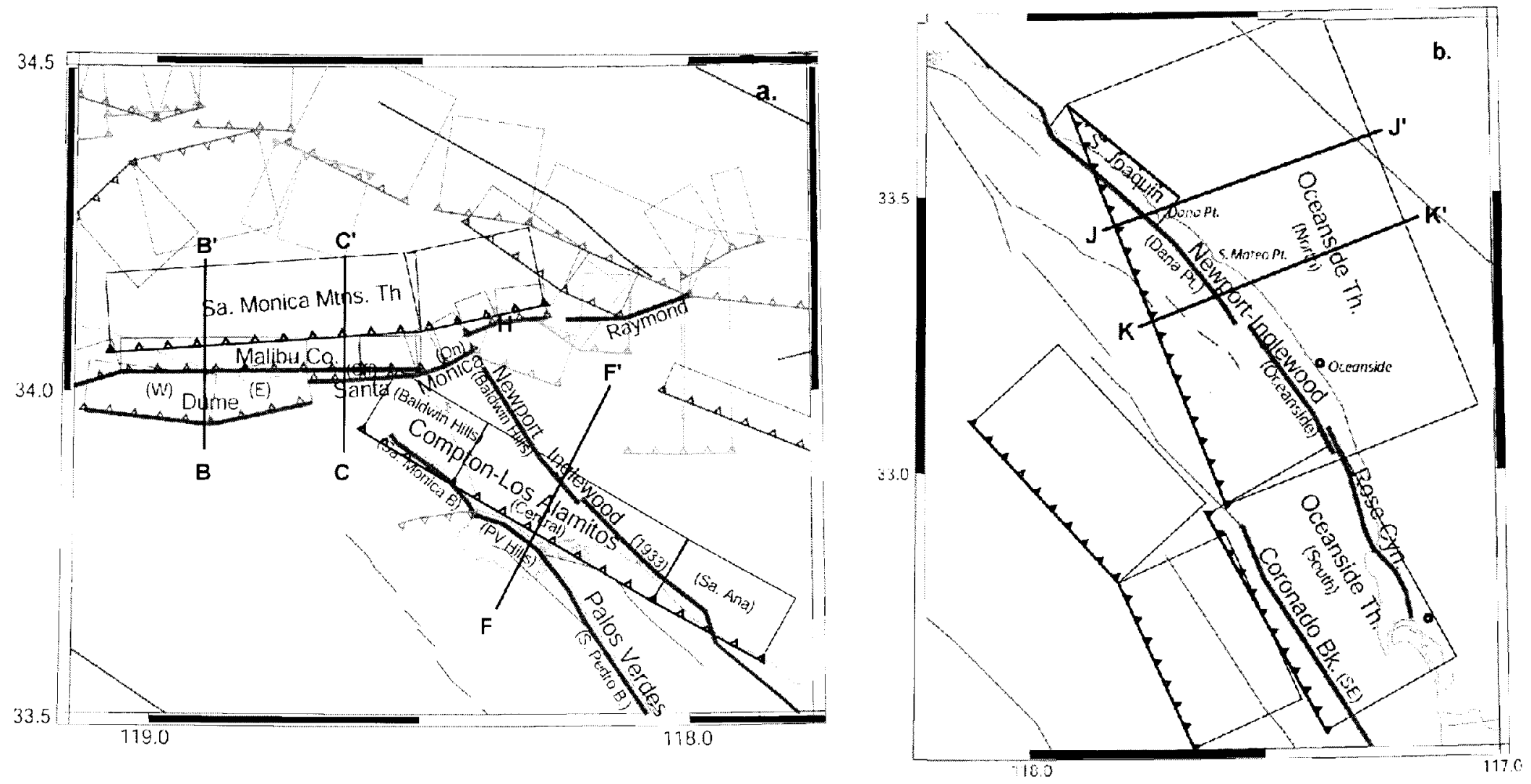

Figure 1: Maps of two sections of the earthquake source model. Rectangles show surface projections of dipping faults. Blind thrust/reverse faults discussed in text shown in yellow, barbs on upper edge. Hollywood fault denoted $\mathbf{H}$ in $\mathbf{a}$. Fault segments shown in parentheses. 

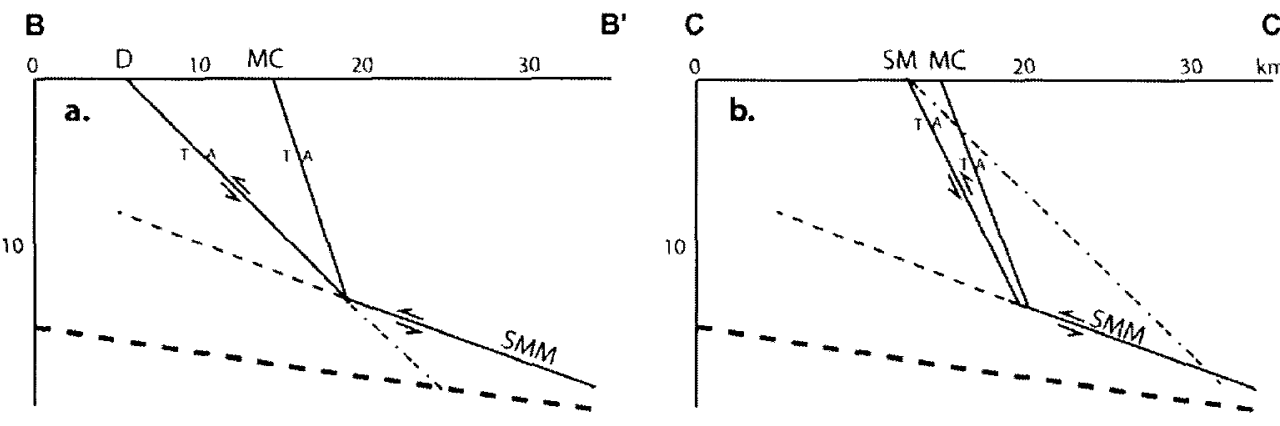

Figure 2: Cross-sections showing Dume (D). Malibu Coast (MC). Santa Monica (SM), and Santa Monica Mtn thrust (SMM) geometries (see Fig. 1 for cross-section locations). Dash-dot lines show alternative geometries of Dume and Sa. Monica faults according to Tsutsumi et al. (2001) interpretation of SM fault/SMM thrust. Alternative (shallow) geometry of SMM thrust shown as light dashed line. Heavy dashed line shows approximate base of seismicity (Magistrale and Zhou, 1996). 


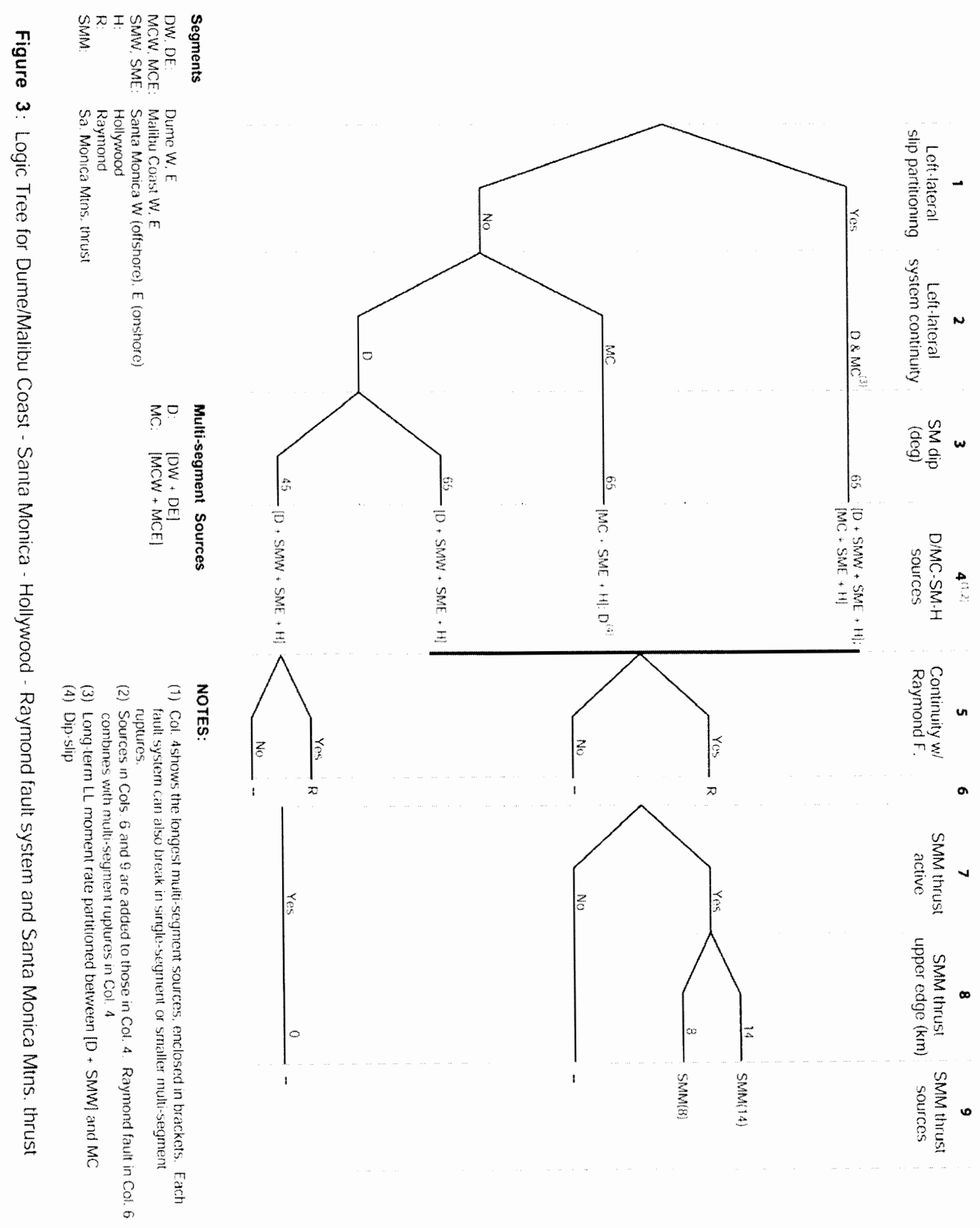



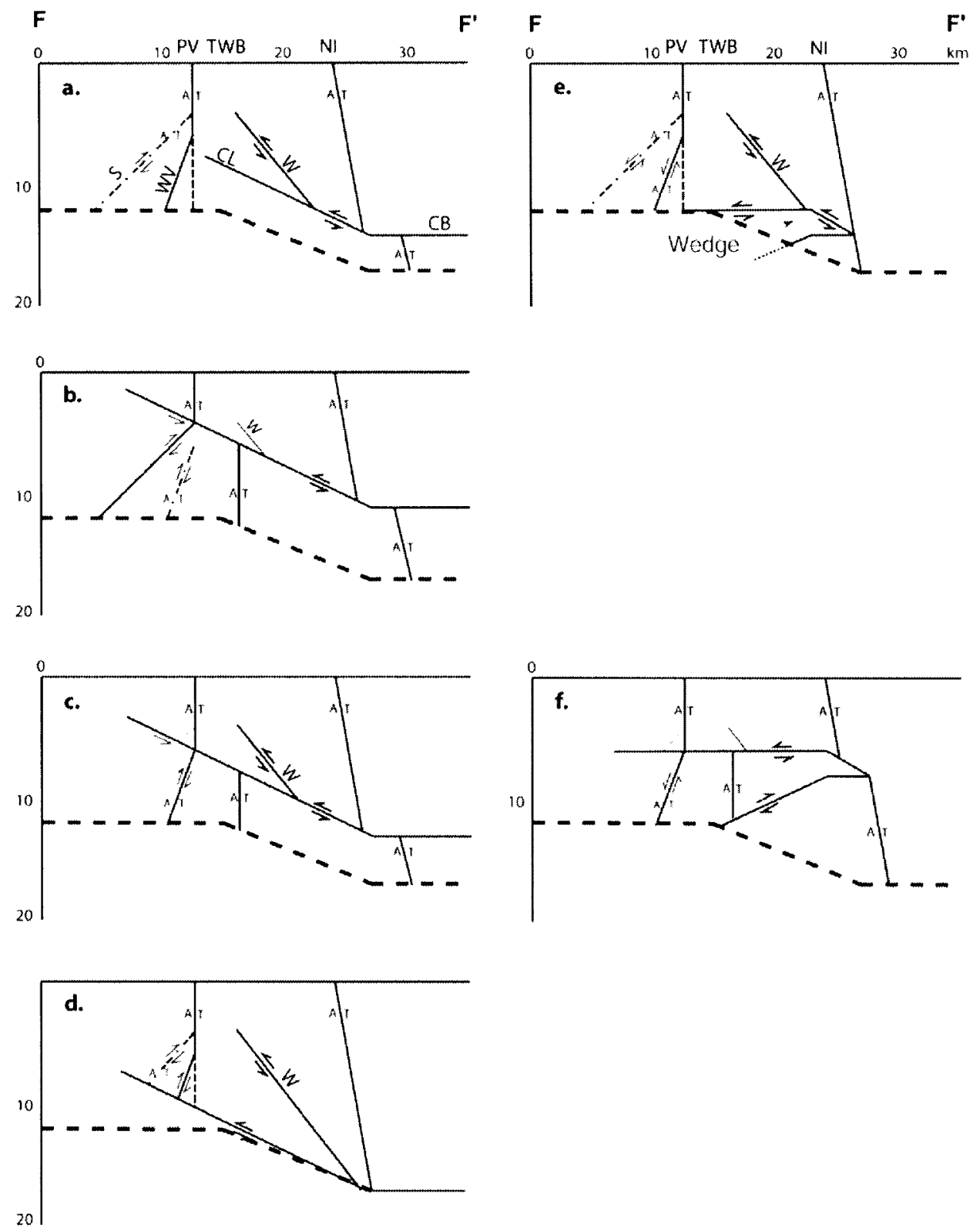

Figure 4: Cross-sections showing alternative Compton-Los Alamitos ramp-flat (CL. CD) and wedge geometries and possible relationships to Newport-Inglewood (NI) and Palos Verdes (PV) faults.

Wilmington thrust (W), and oblique-slip fault planes of Shaw (S) and Ward and Valensise (1996) (WV) $\mathrm{S}$ and $\mathrm{WV}$ are mutually exclusive alternatives (solid and dash-dot) in $\mathbf{a}, \mathbf{b}, \mathbf{d}, \mathbf{e}$. Vertical alternative to SW-dipping deep PV plane shown dashed in a, d, e. Heavy dashed line shows approximate base of seismicity. 


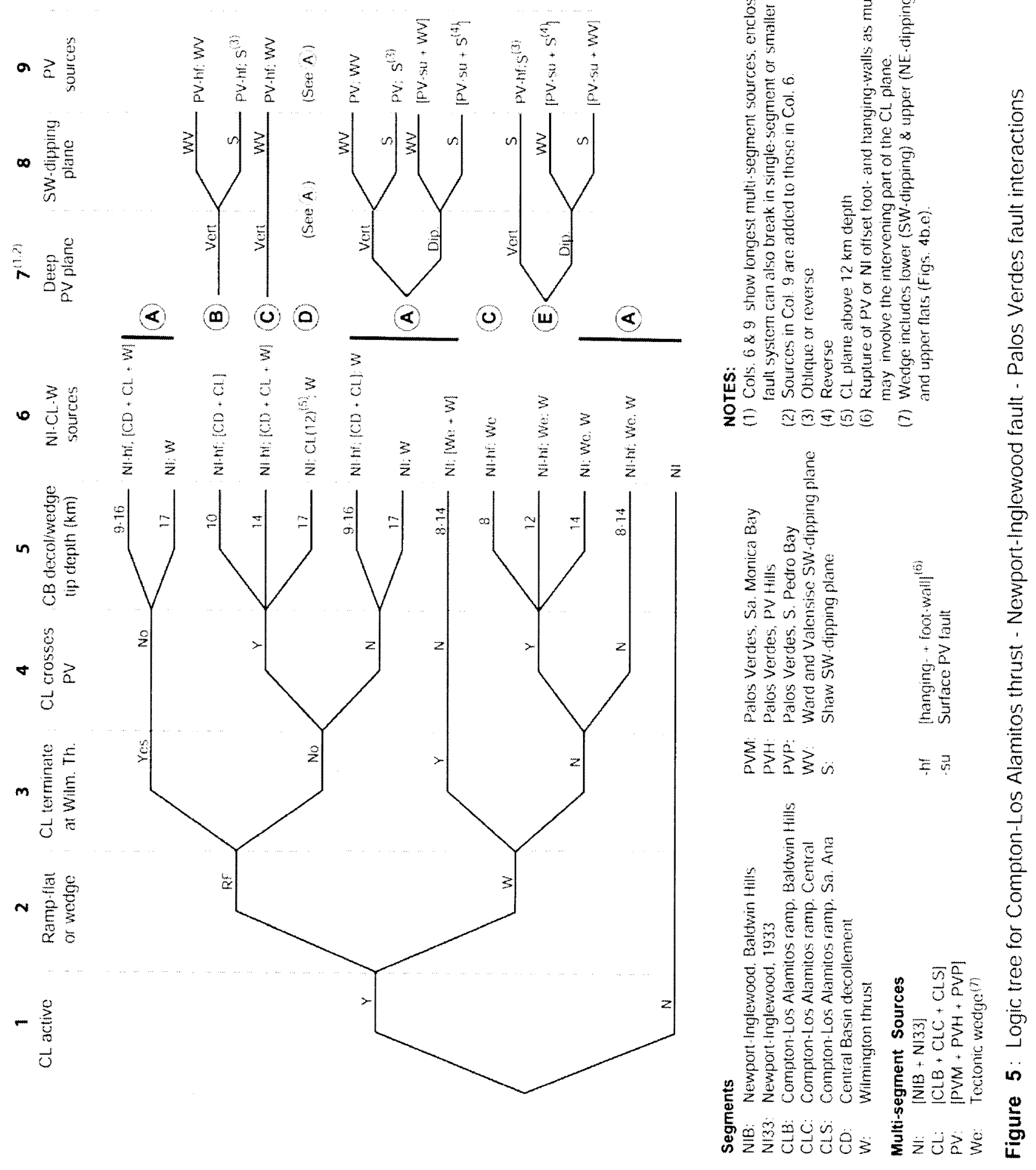



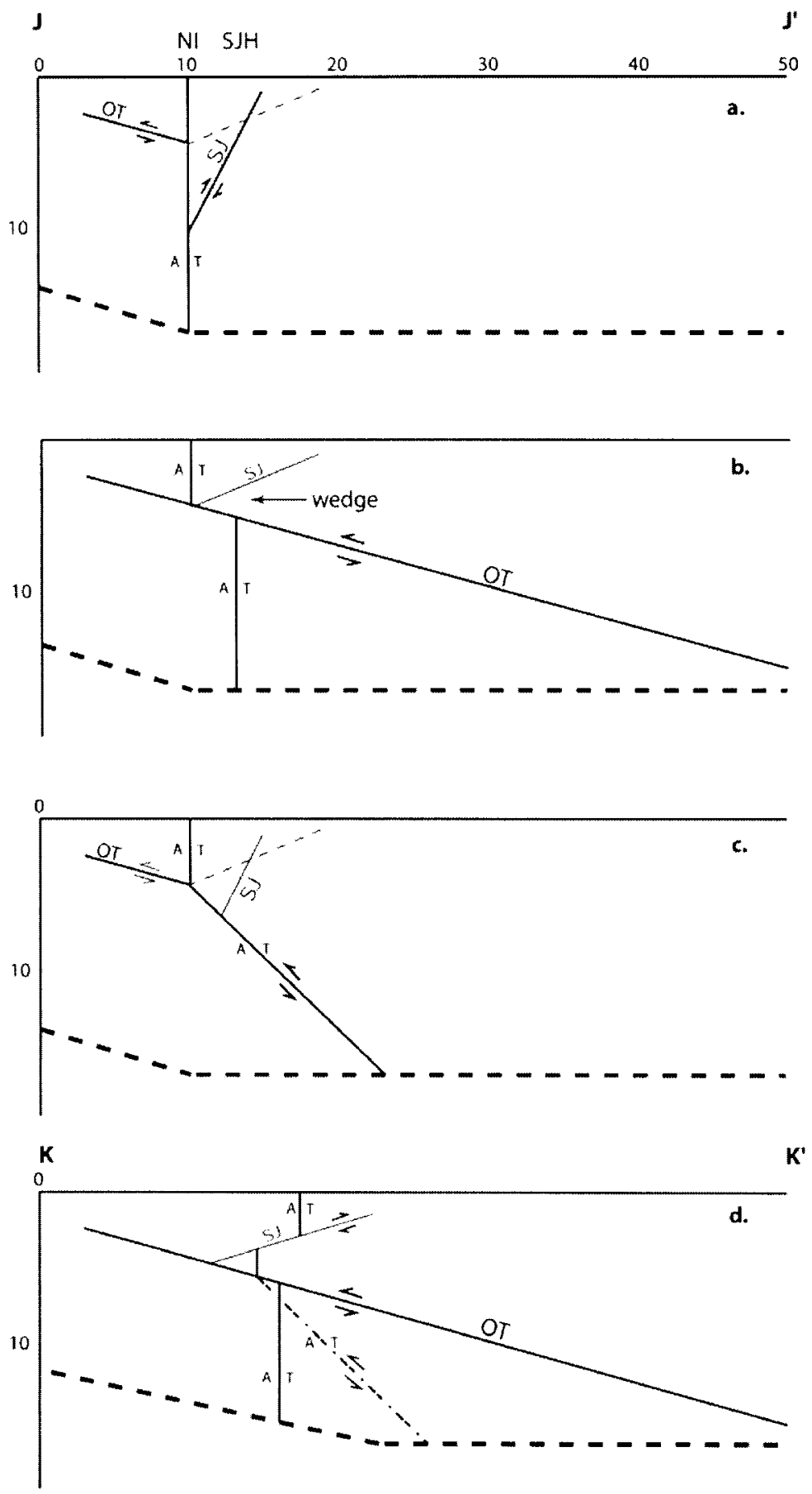

Figure 6: Cross-sections showing alternative relationships among northern Oceanside thrust (OT) offshore Newport-Inglewood fault (NI) and blind fault (SJ) under San Joaquin Hills (SJH). Steep- anc shallow-dipping alternative geometries for SJ shown as solid and dashed, respectively. Obliquel partioned slip alternative shown as dash-dot in section KK' (d). Heavy dashed line shows approximate base of seismicity 


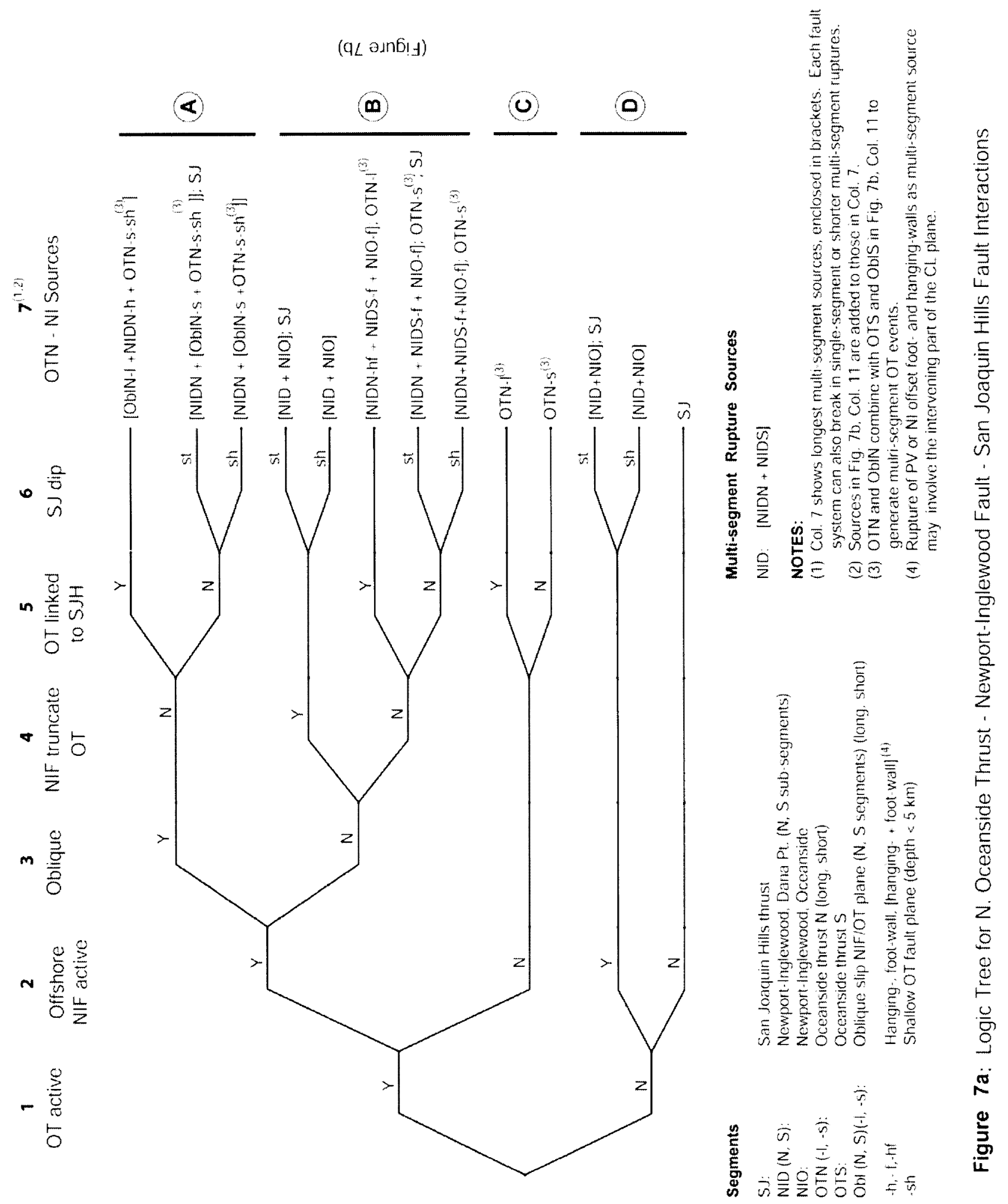




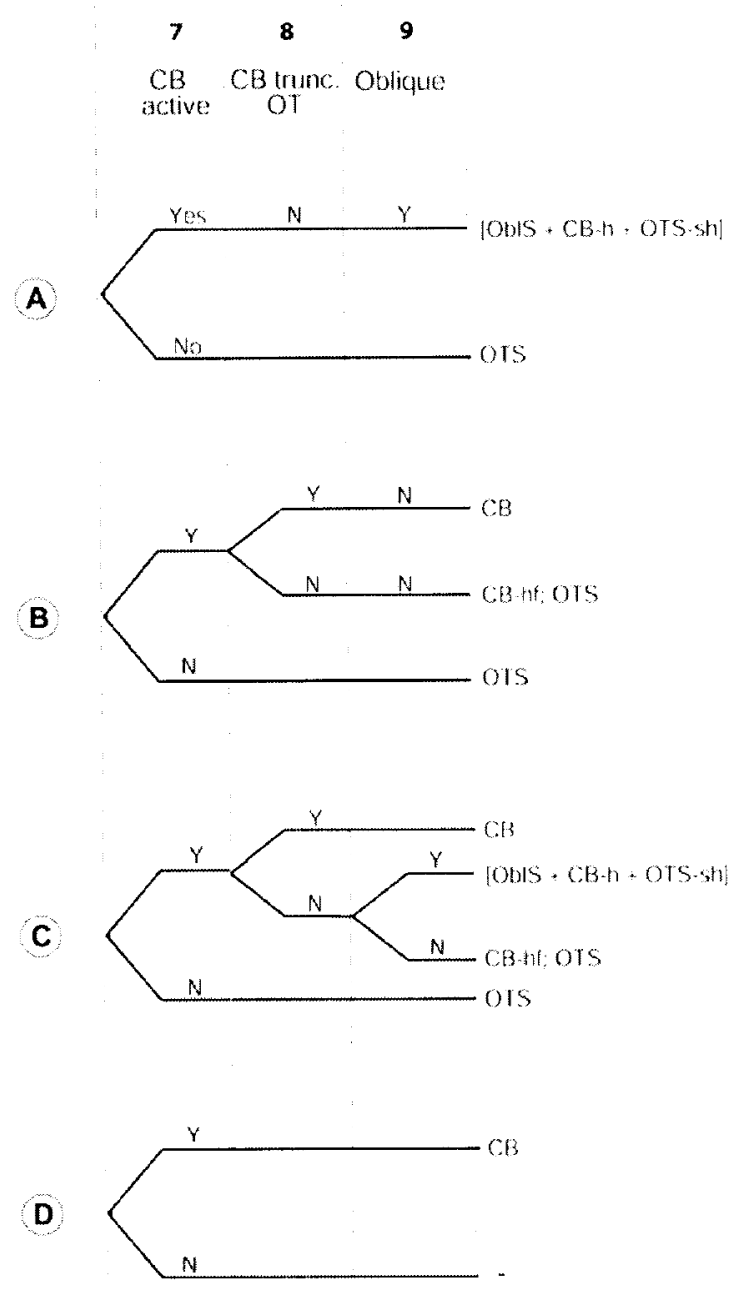

Figure 7b: Logic Tree for S. Oceanside Thrust - Coronado Bank Fault Interaction 